\title{
Seasonal distribution and succession of dominant phytoplankton groups in the global ocean: A satellite view
}

\author{
S. Alvain, ${ }^{1,3}$ C. Moulin, ${ }^{2}$ Y. Dandonneau, ${ }^{4}$ and H. Loisel ${ }^{1}$ \\ Received 27 November 2007; revised 21 February 2008; accepted 29 February 2008; published 2 July 2008.
}

[1] Phytoplankton plays an important role in the global carbon cycle via the fixation of inorganic carbon during photosynthesis. However, the efficiency of this "biological pump of carbon" strongly depends on the nature of the phytoplankton. Monitoring spatial and temporal variations of the distribution of dominant phytoplankton groups at the global scale is thus of critical importance. Recently, an algorithm has been developed to detect the major dominant phytoplankton groups from anomalies of the marine signal measured by ocean color satellites. This method, called PHYSAT, allows to identify nanoeucaryotes, Prochlorococcus, Synechococcus and diatoms. In this paper, PHYSAT has been improved to detect an additional group, named phaeocystis-like, by analyzing specific signal anomalies in the Southern Ocean during winter months. This new version of PHYSAT was then used to process daily global SeaWiFS GAC data between 1998 and 2006. The global distribution of major phytoplankton groups is presented in this study as a monthly climatology of the most frequent phytoplankton group. The contribution of nanoeucaryotes-dominated waters to the global ocean varies from 45 to $70 \%$ depending on the season, whereas both diatoms and phaeocystis-like contributions exhibit a stronger seasonal variability mostly due to the large blooms that occur during winter in the Southern Ocean. Three regions of particular interest are also studied in more details: the Southern Ocean, the North Atlantic, and the Equatorial Pacific. The North Atlantic diatom bloom shows a large interannual variability. Large blooms of both diatoms and phaeocystis-like are observed during winter in the Southern Ocean, with a larger contribution from diatoms. Their respective geographical distribution is shown to be tightly related to the depth of the mixed-layer, with diatoms prevailing in stratified waters. Synechococcus and Prochloroccocus prevail in the Equatorial Pacific, but our data show also sporadic diatoms contributions in this region during La Niña. The observed seasonal cycle and interannual variability of phytoplankton groups in the global ocean suggest that the PHYSAT archive is suitable to study the impact of climate variability on the structure of marine ecosystems.

Citation: Alvain, S., C. Moulin, Y. Dandonneau, and H. Loisel (2008), Seasonal distribution and succession of dominant phytoplankton groups in the global ocean: A satellite view, Global Biogeochem. Cycles, 22, GB3001, doi:10.1029/2007GB003154.

\section{Introduction}

[2] Marine biology plays a major role in biogeochemical cycles in the oceans. More particularly, phytoplankton biological pump participates in regulating the amount of carbon in the atmosphere and is thought to be very sensitive to the forthcoming climate change [Cox et al., 2000; Bopp et al., 2001; Dufresnes et al., 2002; Sarmiento

\footnotetext{
${ }^{1}$ Laboratoire d'Oceanologie et de Geosciences, CNRS-ULCO-USTL, Wimereux, France.

${ }^{2}$ Laboratoire des Sciences du Climat et de L'Environnement, Institut Pierre Simon Laplace, CNRS-CEA-UVSQ, Gif-sur-Yvette, France.

${ }^{3}$ LGMAC, UEA, Norwich, UK.

${ }^{4}$ IRD, Laboratoire d'Oceanographie et du Climat: Experimentations et Approches Numeriques, Institut Pierre Simon Laplace, (UPMC-CNRSIRD), Paris, France.
}

Copyright 2008 by the American Geophysical Union. 0886-6236/08/2007GB003154 et al., 2004; Le Quéré and Metzl, 2004; Le Quéré et al., 2006]. The intensity of both carbon fixation and export is however strongly dependent on the size and composition of phytoplankton cells. It is for example well known that diatoms, which are characterized by large cells with a heavy silicate skeleton, are particularly efficient for carbon export [Lochte et al., 1993; Bopp et al., 2005]. Most current global numerical models used to estimate the marine biological pump thus independently represent the main phytoplankton groups [Kamykowski and Janowitz, 1999; Aumont et al., 2003; Gregg et al., 2003; Moore et al., 2004; Le Quéré et al., 2005].

[3] The validation of these global models is crucial but also particularly difficult because of the lack of global data available on the geographical distribution of the main phytoplankton groups. Although it is well known that diatoms blooms occur every year in the North Atlantic and Pacific Oceans in the springtime and in 
the southern Ocean in winter [Lampitt, 1985; Knox, 1994; Dandonneau et al., 2006], very little is known about their actual duration and location, and even less about their interannual variability. Several other groups have also significant impacts on biogeochemical cycles such as phaeocystis that produces atmospheric Dimethyl Sulfide compounds (DMS) [Belviso et al., 2004]. As for diatoms, our knowledge on the spatial and temporal distributions of phaeocystis blooms, based only on sparse in situ measurements, is limited.

[4] Our current knowledge of the global distribution and seasonal variability of phytoplankton comes mainly from satellite observations: the first ocean color sensor, CZCS, has partially covered the 1979-1986 period, whereas its successors, OCTS, SeaWiFS and MODIS, have enabled a continuous monitoring of phytoplankton since 1997. The chlorophyll-a concentration (Chl-a), which is derived from these satellite observations using a bio-optical algorithm, is commonly used as a proxy of the phytoplankton concentration in surface waters because this photosynthetic pigment is dominant in most phytoplankton groups. Most of ocean color bio-optical algorithms [O'Reilly et al., 1998] rely more or less on the same blue to green ratio of the normalized water leaving radiance (nLw), which quantifies the amount of light exiting the ocean surface. This chlorophyll-a concentration however does not provide any information about which phytoplankton group dominates in surface waters at the time of the measurement.

[5] Recently, a method called PHYSAT has been developed to identify the dominant phytoplankton group simultaneously with Chl-a [Alvain et al., 2005] using ocean color data. This classification technique enables the identification of four major phytoplankton groups, i.e., nanoeucaryotes, Prochlorococcus, Synechococcus, and diatoms. PHYSAT relies on the detection of spectral anomalies of $\mathrm{nLw}$, which were associated to specific phytoplankton groups by using coincident in situ measurements of pigment inventories performed in the framework of the GeP\&CO program [Dandonneau et al., 2004]. It should be noted that in this work the nanoeucaryote group replaces the haptophytes group defined by Alvain et al. [2005]. Indeed, when PHYSAT was developed, the phytoplankton group "haptophytes" was so denominated because it differed from other groups by abnormally high content of 19'hexanoyloxyfucoxanthin, which is usually considered as a diagnostic pigment for haptophytes [Jeffrey and Vesk, 1997]. This pigment however is abundant almost everywhere in the ocean, and in the GeP\&CO data set, it covaries with violaxanthin, alloxanthin and 19'butanoyloxyfucoxanthin [Dandonneau and Niang, 2007], thus implying that the groups characterized by these carotenoid pigments are often found associated to the Haptophytes. These groups are formed by small nanoplanktonic flagellated algae which we now refer to "nanoeucaryotes".

[6] In this paper, we first show that PHYSAT can be extended to the detection of phaeocystis-like blooms, even if further validation is still needed. Then we analyze the monthly global climatology of the distribution of the five phytoplankton groups identified by PHYSAT, using
9 years (1998-2006) of daily SeaWiFS data. We finally present a more detailed analysis of the spatial and seasonal variability of phytoplankton group distribution for three contrasted regions of great importance in terms of biogeochemical cycles, i.e., the North Atlantic, the Equatorial Pacific and the Southern Ocean.

\section{PHYSAT Method}

\subsection{Characteristics and Evolutions}

[7] The PHYSAT approach is based on the identification of specific signatures in the $\mathrm{nLw}$ spectra measured by an ocean color sensor. It is described in detail by Alvain et al. [2005]. Briefly, this empirical method has been established by comparing two kinds of simultaneous and coincident measurements: SeaWiFS nLw measurements and in situ measurements of diagnostic phytoplankton pigments performed in the framework of the GeP\&CO program [Dandonneau et al., 2004]. GeP\&CO cruises have sampled a wide range of water types, from the North Atlantic spring bloom to the oligotrophic subtropical south Pacific. In a first step, four dominant phytoplankton groups were identified within the GeP\&CO data set based on the pigment inventories: diatoms, nanoeucaryotes, Synechococcus and Prochlorococcus. Note that here, "dominant" has been defined by Alvain et al. [2005] as situations in which a given phytoplankton group is a major contributor to the total pigment. In a second step, coincident SeaWiFS nLw spectra between 412 and $555 \mathrm{~nm}$ were transformed into specific normalized water-leaving radiance $\left(\mathrm{nLw}^{*}\right)$ spectra in order to evidence the second-order variability of the satellite signal. This was done by dividing the actual $\mathrm{nLw}$ by a mean $\mathrm{nLw}$ model $\left(\mathrm{nLw}^{\mathrm{ref}}\right)$, which depends only on the standard SeaWiFS Chl-a.

[8] Alvain et al. [2005] showed that every dominant phytoplankton group sampled during GeP\&CO is associated with a specific nLwV* spectrum. They defined a set of criteria to characterize each group in function of its $\mathrm{nLw}^{*}$ spectrum. These criteria can be applied to global daily SeaWiFS GAC archive to get global monthly maps of the most frequent group of dominant phytoplankton, as shown in Figure 1a for January 2002. When no group prevails over the month, the pixels are associated with an "unidentified" phytoplankton group. The only difference between the PHYSAT method used in this study and that of Alvain et al. [2005] is the use of a new $\mathrm{nLw}^{\text {ref }}$ model. The former model was indeed calculated from a large SeaWiFS data set extracted along the GeP\&CO ship track for 2001, whereas the new one was obtained by taking into account all SeaWiFS data available for all the geographical areas of the same year, so that it includes data from the Southern Ocean. This modification led to slight changes of the criteria used to identify the four initial phytoplankton groups, as shown in Table 1. Global results for nanoeucaryotes, Prochlorococcus, Synechococcus and diatoms presented in Figure $1 \mathrm{~b}$ are very close to that obtained with the original PHYSAT method shown in Figure 1a. The main difference between Figures $1 \mathrm{a}$ and $1 \mathrm{~b}$ is that diatom blooms are more 

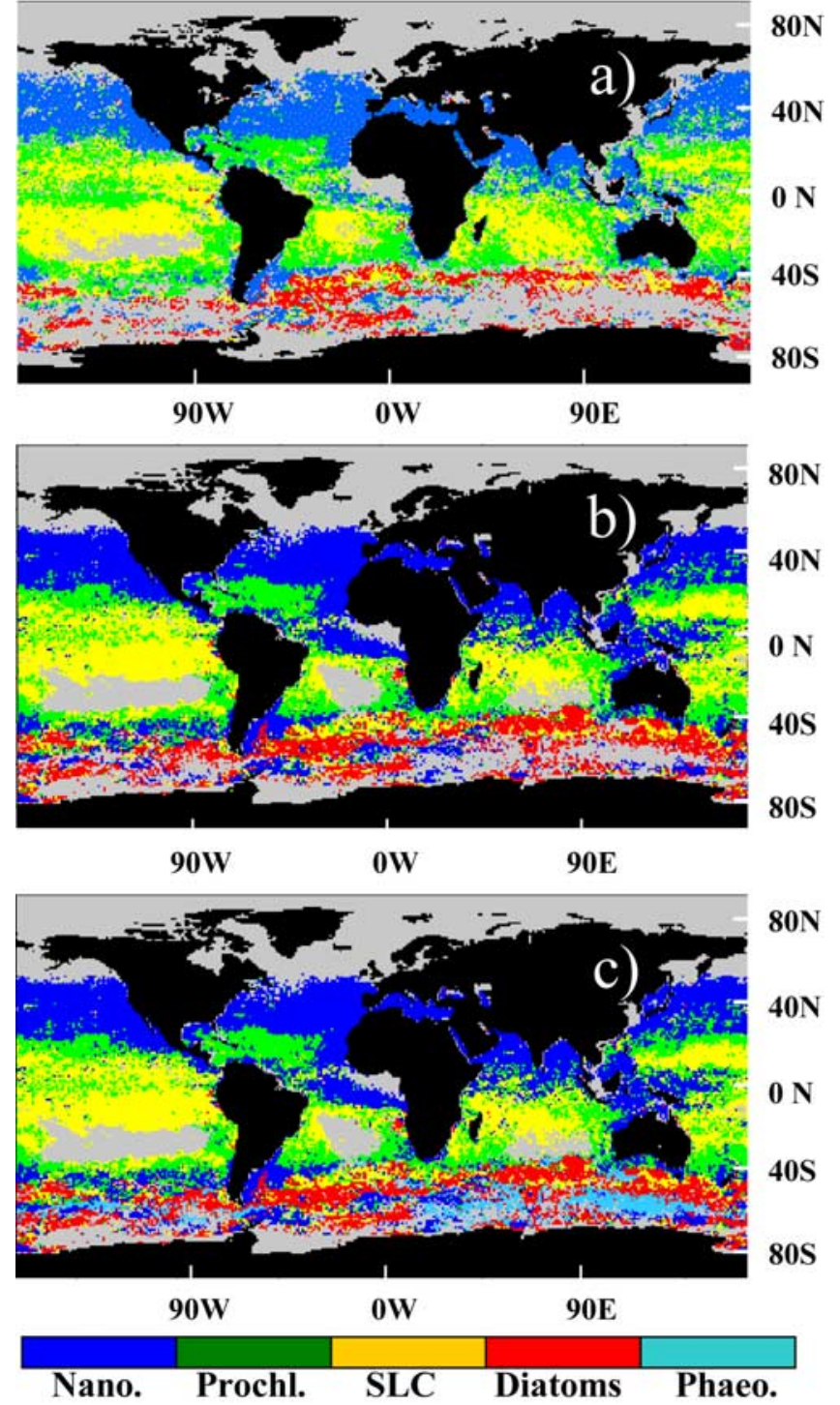

Figure 1. Maps of the dominant phytoplankton group for January 2002 obtained from (a) the standard PHYSAT method of Alvain et al. [2005], (b) the improved PHYSAT method used in this study, and (c) the improved PHYSAT method with the additional phaeocystis-like group. pronounced in the Southern Ocean as well as in upwelling regions when the new PHYSAT is applied.

\subsection{Phaeocystis-Like: An Additional Phytoplankton Group for PHYSAT}

[9] Figures $1 \mathrm{a}$ and $1 \mathrm{~b}$ show that some regions are characterized by a large number of unidentified pixels. This can be easily explained at high latitude in the Northern Hemisphere because of the low sun angles, in the equatorial Atlantic where the aerosol optical thickness due to Saharan dust plumes is often above 0.15 (the maximum value allowed by PHYSAT), as well as in the ultra-oligotrophic subtropical gyres in the southern Pacific and Atlantic where Chl-a values are often below $0.04 \mathrm{mg} . \mathrm{m}^{-3}$ (the minimum value allowed in PHYSAT). On the contrary, the large number of unidentified pixels is surprising in the southern Ocean during summer because all selection criteria are fulfilled for most pixels in this region. Considering the coherence of these spatial structures, it is likely that they correspond to a specific phytoplankton group or at least to a given ecosystem structure. Unfortunately, the GeP\&CO cruises have not sampled these waters. Several other campaigns in the Southern Ocean have however highlighted the frequent occurrence of phaeocystis blooms [Goffart et al., 2000; Smith et al., 2003; Croot et al., 2004; Schoemann et al., 2005]. Phaeocystis is known for its particular optical properties due to the white mucus exuded by cells during the blooming season.

[10] We examined the unidentified $\mathrm{nLw}^{*}$ spectra in this region and we found that most of them are very similar in both amplitude and spectral shape. The mean spectrum of these unclassified pixels is characterized by $\mathrm{nLw}^{*}$ values close to those of diatoms at $443 \mathrm{~nm}$, higher between 490 and $555 \mathrm{~nm}$, and lower at $412 \mathrm{~nm}$, as shown in Figure 2. Similarly to what was done by Alvain et al. [2005], we have defined in Table 1 a range of acceptable $\mathrm{nLw}^{*}$ values for this new class of spectra. These criteria were added to the new PHYSAT method to process the global SeaWiFS archive. Figure 1c shows in light blue the location of these supplementary classified pixels for January 2002. This figure confirms that large parts of the Southern Ocean have optical properties that belong to this additional class of $\mathrm{nLw}^{*}$ spectrum. These spectra are also detected during summer in more restricted area like in the North Sea, where

Table 1. Characteristics of nLw* Spectra for the Six Phytoplankton Groups Detected With PHYSAT

\begin{tabular}{|c|c|c|c|c|c|c|}
\hline & $412 \mathrm{~nm}$ & $443 \mathrm{~nm}$ & $490 \mathrm{~nm}$ & $510 \mathrm{~nm}$ & $555 \mathrm{~nm}$ & Additional Criteria \\
\hline Nanoeuc. min. & 0.4 & 0.55 & 0.6 & 0.6 & 0.6 & $\mathrm{nLw}^{*} 412<\mathrm{nlw} * 443$ \\
\hline Nanoeuc. max. & 0.8 & 0.9 & 0.95 & 1.0 & 1.0 & nLw*443< nlw*490 \\
\hline Prochloroc. min & 0.8 & 0.9 & 0.9 & 0.9 & 0.9 & $\ldots$ \\
\hline Prochloroc. max & 1.0 & 1.0 & 1.0 & 1.0 & 1.0 & $\ldots$ \\
\hline Synechococcus min. & 1.0 & 1.0 & 1.0 & 1.0 & 1.0 & $\ldots$ \\
\hline Synechococcus max. & 1.2 & 1.2 & 1.15 & 1.15 & 1.15 & $\ldots$ \\
\hline Diatoms min. & 1.2 & 1.2 & 1.15 & 1.15 & 1.15 & $\mathrm{nLw} * 412>\mathrm{nlw} * 490$ \\
\hline Diatoms max. & 2.2 & 1.8 & 1.5 & 1.4 & 1.4 & $\mathrm{nLw}^{*} 555<\mathrm{nlw}^{*} 490$ \\
\hline Phaeocystis-like min. & 1.3 & 1.4 & 1.4 & 1.4 & 1.4 & $\mathrm{nLw} * 412<$ nlw*443 \\
\hline Phaeocystis-like max & 1.5 & 1.6 & 1.6 & 1.6 & 1.6 & nLw*443< nlw*490 nLw*510> nlw*555 \\
\hline Coccolithes. - bloom min. & 2.5 & 2.5 & 2.5 & 2.5 & 2.5 & \\
\hline Coccolithes. - bloom max. & 6.0 & 6.0 & 6.0 & 6.0 & 6.0 & \\
\hline
\end{tabular}




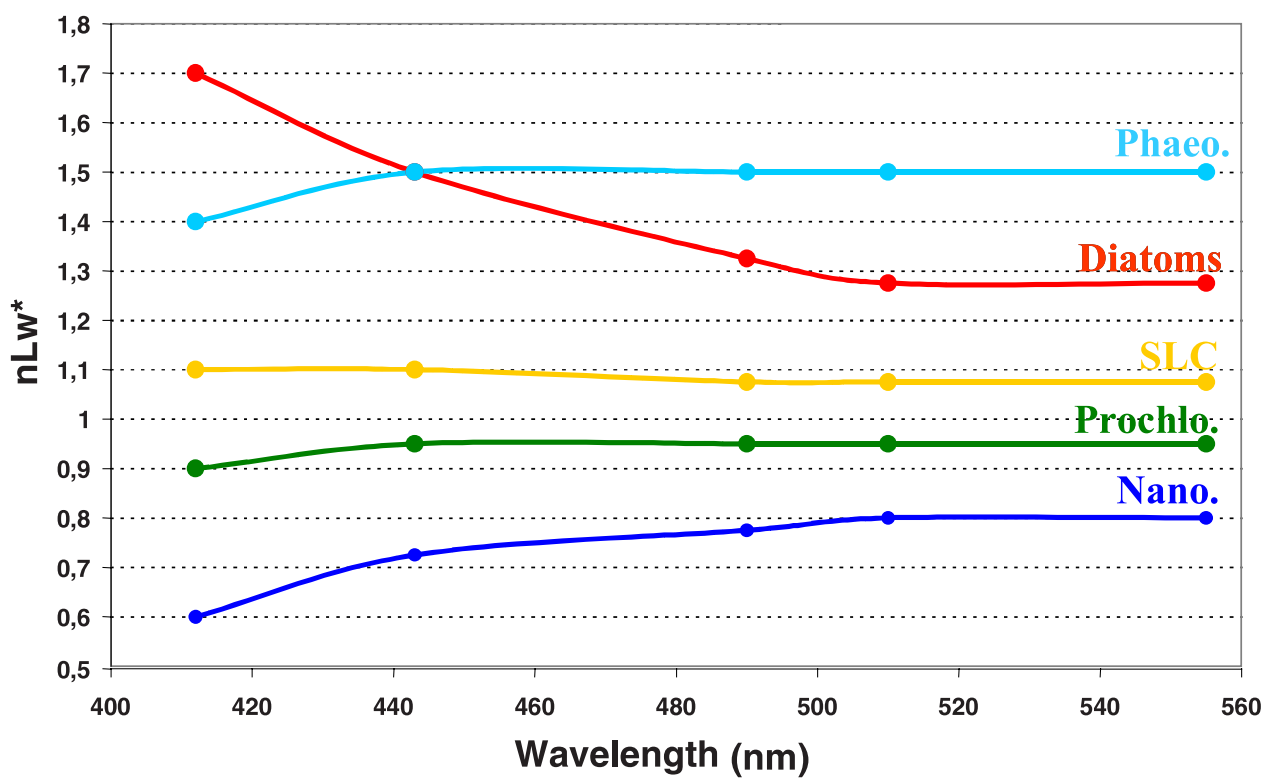

Figure 2. Mean nLw* spectra for the five PHYSAT phytoplankton groups: diatoms in red, nanoeucaryotes in blue, Synechococcus in yellow, Prochlorococcus in green, and phaeocystis-like in light blue.

limited but intense phaeocystis blooms are often observed [Lancelot et al., 1994], and the North Pacific, and from time to time in the North Atlantic in spring and summer.

[11] This additional group is of strong interest for climate studies since phaeocystis blooms can be as effective as diatoms blooms in exporting carbon toward the deep ocean [DiTullio et al., 2000]. They are also important producers of Dimethyl Sulfide (DMS), the precursor of secondary sulfate aerosols [Belviso et al., 2004]. Despite the lack of direct validation, we propose here to add the identification of a "phaeocystis-like" group to this new version of PHYSAT.

\subsection{Coccolithphorids Blooms}

[12] Coccolithophorids were the first phytoplankton group detected from space [Brown and Yoder, 1994]. Indeed, coccolithophorid cells have a spherical shape made of an assemblage of calcium carbonate plates. When the cell dies, these plates are released and produce the well known milky turquoise color in ocean color imagery. This is

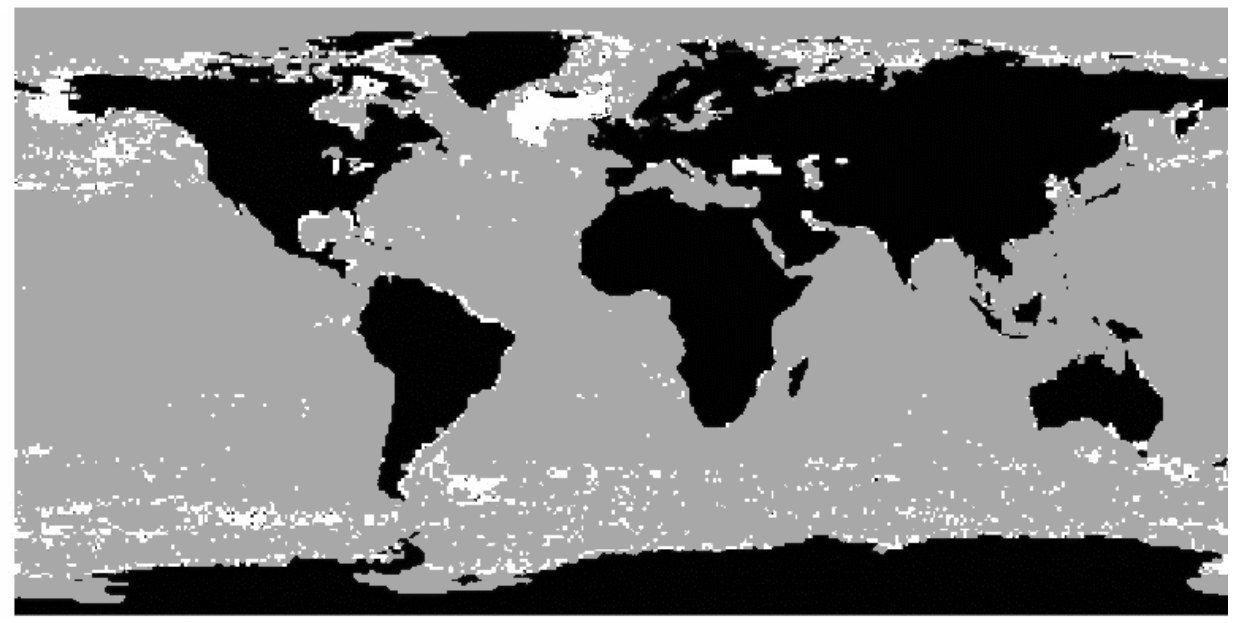

Figure 3. Occurence of Coccolithophorid blooms (in white) obtained with PHYSAT from SeaWiFS data over the 1997-2006 period, using the cumulative approach used by Iglesias-Rodriguez et al. [2002]. Each pixel that has been identified once or more as a Coccolithophorid bloom over the 10-year period is displayed in white. 

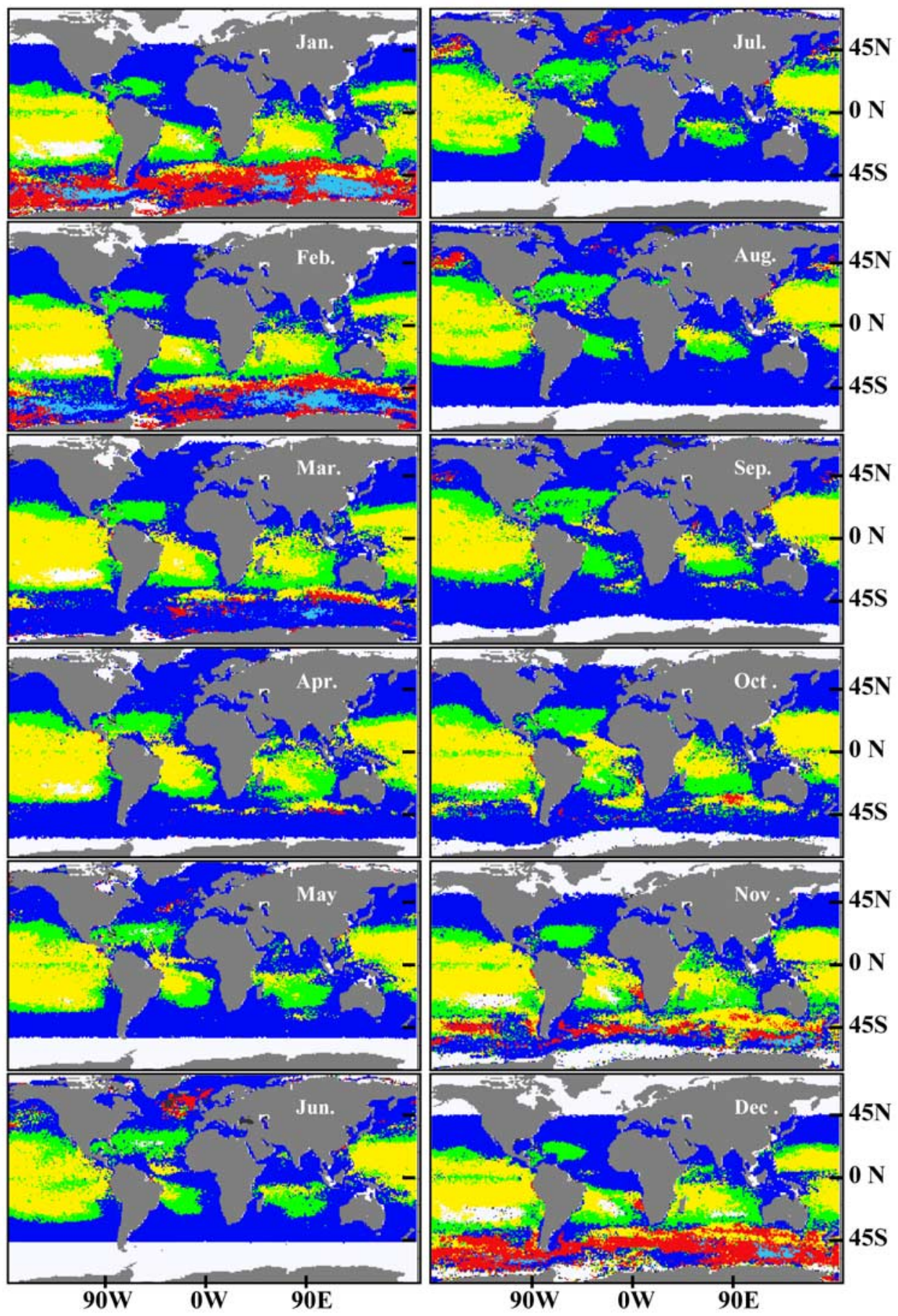

Figure 4. Monthly climatology (1998-2006) of the dominant phytoplankton group.

particularly the case for the "Emiliania huxleyi" species, which is capable of forming large blooms, from over hundred kilometers scale. Those blooms are significant in terms of both climate impact via the export of carbonate and biogeochemical cycles through the emission of chemical compounds.

[13] As the location of major coccolithophorid blooms are well-known (e.g., south of Iceland in summer or in the
Baltic Sea), we searched for specific $\mathrm{nLw}^{*}$ anomalies in these regions, as we did for phaeocystis in the previous section. We found that coccolithophorid blooms are associated to very high $\mathrm{nLw}^{*}$ values at all the wavelengths (see Table 1), which is an expected result for those very bright cells. Figure 3 shows that the use of these criteria within PHYSAT leads to global maps that are exactly the same as those obtained with former methods [e.g., Iglesias-Rodriguez 


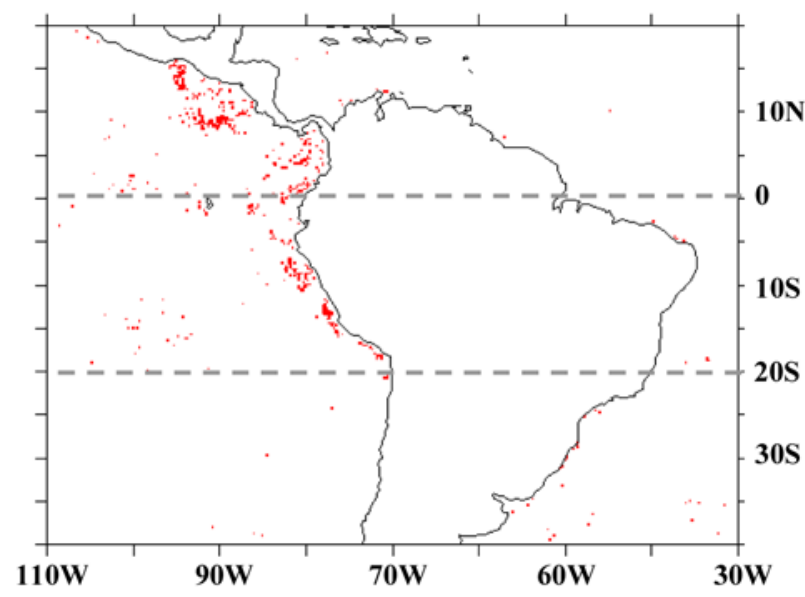

Figure 5. Detection of diatom blooms in the Peru-Chile upwelling in June 2001 using PHYSAT at a $\frac{1}{4}^{\circ}$ resolution.

et al., 2002]. However, it turned out that the SeaWiFS data used by the PHYSAT method, ie. Level 3 daily GAC products, are screened to remove coccolithophorid blooms using a threshold on nLw during the data processing, so that our PHYSAT results, as former methods, likely underestimate the actual size of coccolithophorid blooms. Note that information about the coccolithophorid screening are not available in Level 3 GAC products and that a complete reprocessing of the SeaWiFS Level 2 archive would be necessary to overcome this problem. We have thus decided to not include this group to our climatology.

\subsection{Data Processing}

[14] The new PHYSAT defined above has been applied to all SeaWiFS daily L3-binned GAC data between 1998 and 2006 (processing version 5.2). These data were available from the NASA/GSFC/DAAC web site (http://oceancolor .gsfc.nasa.gov/). Daily phytoplankton group maps at a resolution of $1 / 12^{\circ}$ were used to generate monthly maps of most frequently identified dominant phytoplankton group at a $1^{\circ}$ resolution by selecting the group that had been retrieved for at least half of the valid (including unidentified) pixels within each $1^{\circ} \times 1^{\circ}$ grid box. Note that no phytoplankton group is assigned to a grid box for which no phytoplankton group dominates or for which unidentified pixels prevail. PHYSAT data used in this work are available at http://log.univ-littoral.fr/Physat.

\section{Global Climatology of Phytoplankton Groups}

\subsection{Geographical Distribution}

[15] Figure 4 shows the monthly climatology (19982006) of the most frequent phytoplankton groups. These global results show well-defined and persistent patterns of phytoplankton that are similar to those obtained by Alvain et al. [2005] for the year 2001. Prochlorococcus and Synechococcus are mostly detected in oligotrophic tropical waters because the small size of these pico-plankton cells, and hence their large surface-to-volume ratio, makes them less sensitive to nutrient limitation than larger phytoplankton groups [Longhurst, 2007].
[16] Prochlorococcus are nevertheless preferentially observed between $25^{\circ}$ and $35^{\circ} \mathrm{N}$ and between $20^{\circ}$ and $35^{\circ} \mathrm{S}$, whereas Synechococcus prevail in equatorial waters. Prochlorococcus and nanoeucaryotes prevail in the North Atlantic with a Prochlorococcus shift northward in summer and fall as observed at the BATS station in the Sargasso Sea [DuRand et al., 2001]. Prochlorococcus and Synechococcus seem also to vary more in space in the Pacific Ocean. For example, Synechococcus is seldom dominant during northern summer in the Atlantic where it is replaced by both Prochlorococcus and nanoeucaryotes. These results are coherent with analysis of Atlantic Meridional Transec (AMT) transects data by Zubkov et al. [2000]. Several processes are likely controlling this difference in phytoplankton group succession in the two tropical oceans. Zubkov et al. showed that Prochlorococcus and Synechoccoccus are associated with different surface temperature water, but other elements such as iron availability due to differences in aerosol deposition (desert dust in the Atlantic), river inputs (Amazon and Congo in the Atlantic) and vertical mixing are also proposed by Longhurst [2007]. Nanoeucaryotes are also widely present at middle- and high-latitude waters. They can also be found in the southeastern Pacific Ocean during spring and summer, as well as in the northeastern Indian Ocean.

[17] As expected, a diatoms bloom is observed in the North Atlantic Ocean during spring. This bloom starts in the South-East of the basin in May around $40^{\circ}$ North and moves northward up to $60^{\circ} \mathrm{N}$ in August. A similar evolution of the North Pacific diatoms bloom is observed, but delayed by 1 month.

[18] During the austral summer, large blooms of both diatoms and phaeocystis-like are observed in the southern Ocean. As in the Northern Hemisphere, diatoms blooms move poleward from November to January. These blooms will be discussed in more details in section 4. Finally, diatoms are also frequently observed, in area characterized by strong upwelling conditions, even from climatology monthly maps at a $1^{\circ}$ resolution. Thus diatoms are dominant near Angola or Namibia coasts in the Atlantic or along the Equator and Peru coasts in the Pacific. Note that the observation of coastal diatoms bloom due to upwelling conditions are not optimal at $1 \times 1^{\circ}$ of resolution because of the limited spatial extension of these blooms. A spatial resolution of $\frac{1}{4}^{\circ}$ or less at one month scale maximum would be more adapted as shown in Figure 5. This is why diatoms bloom in the upwelling area are not always visible on the climatology maps in Figure 4.

\subsection{Validation}

[19] The geographical distributions and seasonal successions of major phytoplankton groups showed in Figure 4 are in good agreement with previous studies [e.g., Dandonneau et al., 2004; Zubkov et al., 2000; Marty and Chiavérini, 2002; DuRand et al., 2001; Steinberg et al., 2001; Longhurst, 2007], as already discussed by Alvain et al. [2005] from the analysis of year 2001. We present here a tentative validation of the global monthly PHYSAT products using the two main consistent global pigment inventories data sets available: NOMAD [Werdell and Bailey, 2005] and GeP\&CO 


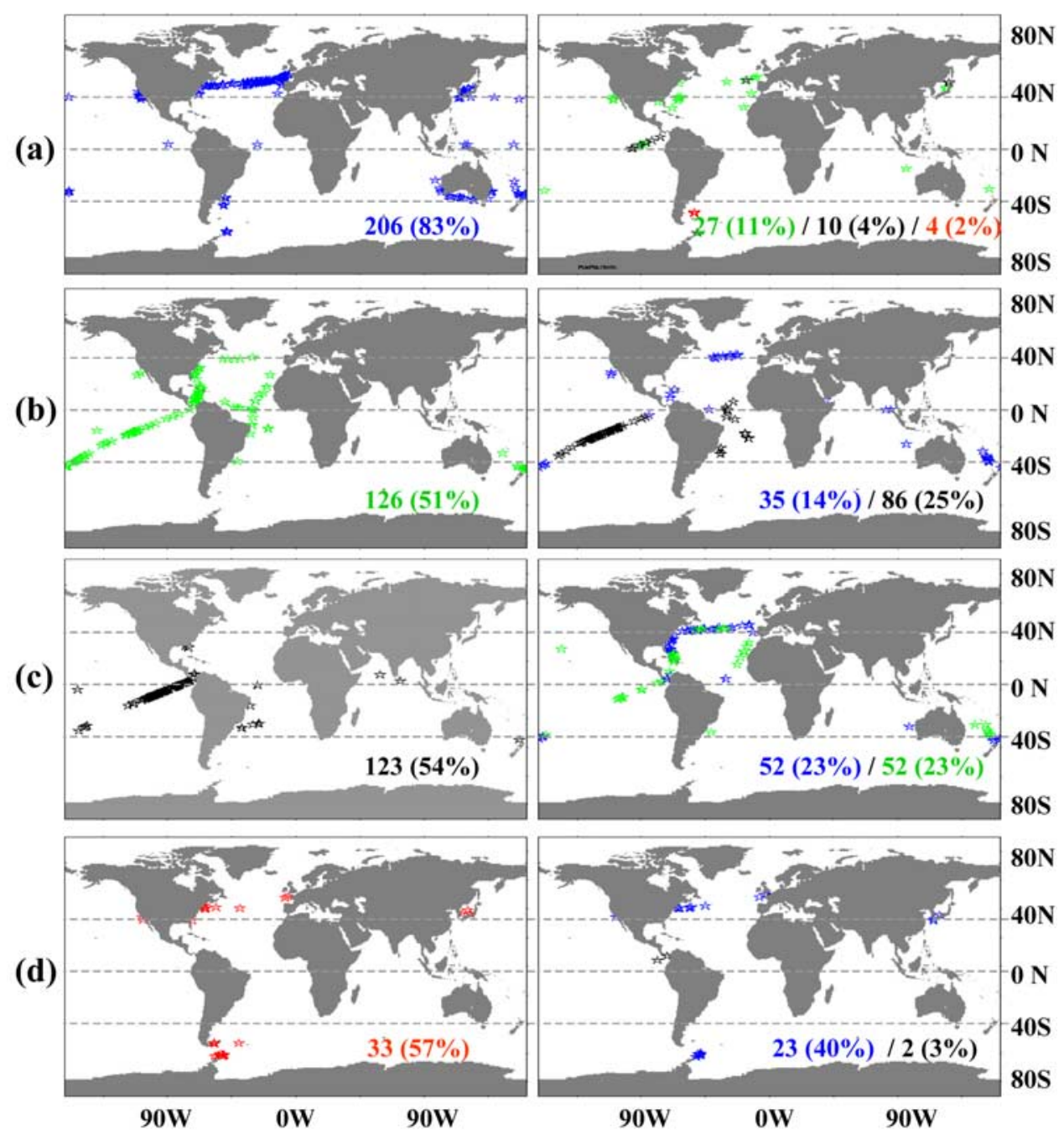

Figure 6. Validation of PHYSAT using GeP\&CO and NOMAD data sets (see text): Each map displays the localization, the number and the percentage of valid (left column), and wrong (right column) PHYSAT identifications for (a) nanoeucaryotes, (b) Prochlorococcus, (c) Synecochoccus, and (d) diatoms. Wrong identifications are separated by groups (blue for nanoeucaryotes, green for Prochlorococcus, black for Synechococcus, and red for diatoms).

[Dandonneau et al., 2004]. We removed from the latter data set the $15 \%$ of data that were used for developing the PHYSAT method (see Alvain et al. [2005] for details). These two data sets contain the seven essential pigments used to labelize phytoplankton groups (Chlorophyll-a, Phaeophytin-a, Divinyl Chlorophyll-a, Peridinine, Fucoxanthin, 19'hexanoyloxyfucoxanthin and Zeaxanthin), and 1286 pigments inventories \pm 378 from NOMAD and 908 from $\mathrm{GeP} \& \mathrm{CO}$ ) satisfying our quality criteria, i.e., case 1 waters from Patt et al. [2003], Chl-a concentration values between 0.04 and $4 \mathrm{mg} \cdot \mathrm{m}-3$ and Phaeophytine-a relative concentration lower than 0.3 , were selected. Over these 1286 inventories, 986 were successfully associated with one dominant phytoplankton group using the criteria on pigments of Alvain et al. [2005]. 779 of these inventories (233 from NOMAD and 546 from GeP\&CO) were successfully associated with a phytoplankton group in the PHYSAT monthly archive (1997-2006) for the month and the $1^{\circ} \times$ $1^{\circ}$ grid cell that corresponds to the measurement. These inventories contain 247 water samples dominated by nanoeucaryotes, 247 by Prochlorococcus, 227 by Synechococcus and 58 by diatoms.

[20] Figure 6 provides a synthetic view of this validation exercise, by showing, for each of the four PHYSAT original groups, the localization, the number and the percentage of data properly (on the left) and erroneously (on the right) identified by PHYSAT. $87 \%$ of the pigments inventories corresponding to nanoeucaryotes are associated with the same phytoplankton group in the PHYSAT monthly product. PHYSAT leads to only a limited number of wrong identifications, mostly Prochlorococcus in the Northern Hemisphere and Synechococcus from one campaign in the Equatorial Pacific. 


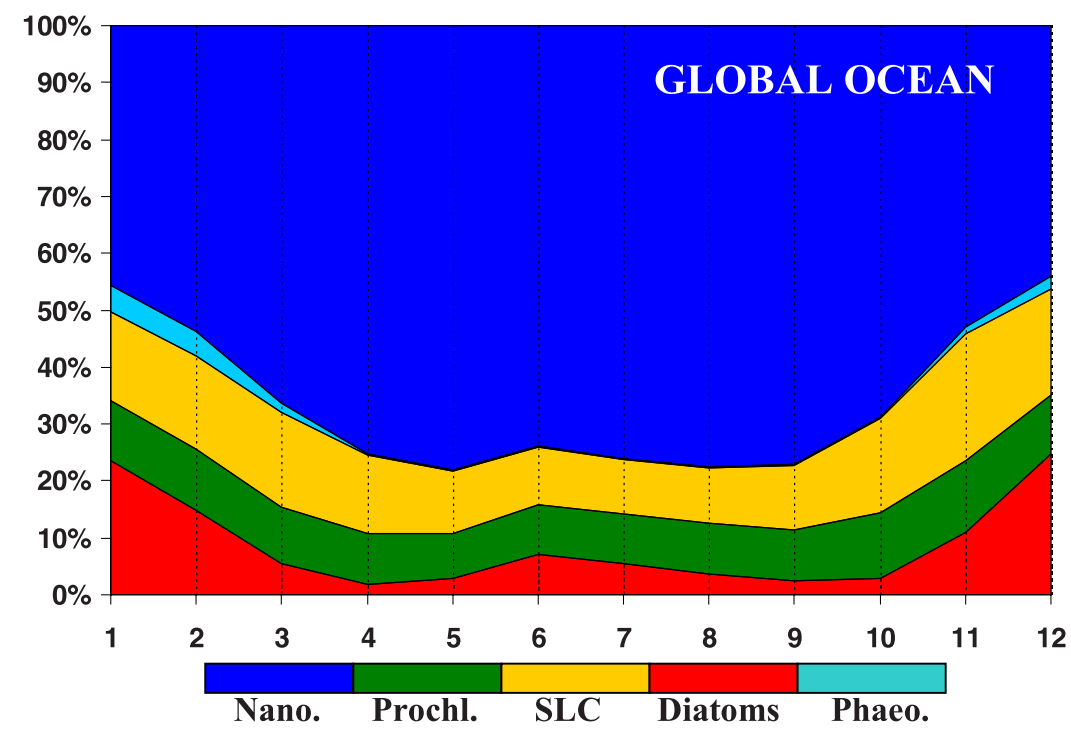

Figure 7. Mean seasonal evolution over the 1998-2006 period of the relative contribution of each phytoplankton group to the mean chlorophyll-a concentration for the global ocean, as obtained from the monthly climatology in Figure 4.

[21] The result of this validation is less satisfactory for both Prochloroccocus and Synechococcus, with slightly more than $50 \%$ of proper identification in the PHYSAT monthly products. Interestingly, most erroneous identifications for one of these two groups is associated with the other group, which suggests that there is an uncertainty in PHYSAT between Prochlorococcus and Synechococcus. This particularly the case in the Equatorial Pacific, where the two groups can be found. Note that this result is not surprising considering the close characteristics (geographical distribution, size and specific signal in PHYSAT) of this two groups.

[22] A significant fraction (57\%) of Diatom pigment inventories are properly identified in $1 \times 1^{\circ}$ monthly PHYSAT products of dominant groups. Most erroneous identifications are associated with nanoeucaryotes and are found in waters which are shown in Figure 4 to be alternatively dominated by nanoeucaryotes and diatoms, essentially in the North Atlantic and Pacific and in the Southern Ocean. The temporal and spatial resolution used for this validation likely explains this result for a blooming phytoplankton group as diatoms. Another explanation for this result is that PHYSAT does not apply to pixels with Chl-a above $4 \mathrm{mg} \cdot \mathrm{m}^{-3}$. This validation suggests that our global PHYSAT monthly climatology products certainly underestimates the diatom abundance.

\subsection{Seasonal Succession}

[23] Figure 7 shows the climatological (1998-2006) monthly mean evolution of the fraction of the global mean Chl-a for the various PHYSAT groups. To do so, every daily pixel of the 9-year SeaWiFS archive for which a dominant group is detected has been associated with its corresponding Chl-a to allow the computation of the monthly climatological mean Chl-a of each group. This figure shows that nanoeucaryotes are prevailing all yearlong, and contribute for more than $70 \%$ during spring and summer months to almost 50\% during winter. Prochlorococcus account for slightly less of the global Chl-a (maximum of 10\%) than Synechococcus (15 to $20 \%$ ), mostly because this latter group is usually associated with slightly higher Chlorophyll-a [Alvain et al., 2005]. There is no significant seasonal variation in the contribution of these two groups, even if Synechococcus seems to be more abundant in winter than in summer (from 10 to $15 \%$ ). On the contrary, the Diatom's contribution shows a significant seasonal cycle. The contribution of this group reaches at least 20 to $25 \%$ of the global Chlorophyll-a (considering the diatoms PHYSAT and chlorophyll a underestimation see Alvain et al. [2006]) during winter when the southern Ocean is blooming but accounts for less than 5\% in April, May, September and October. The contribution of phaeocystis-like is much smaller $(<5 \%)$ than that of diatoms, but follows a similar seasonal cycle.

\section{Regional Studies}

4.1. North Atlantic $\left(40^{\circ} \mathrm{N}-70^{\circ} \mathrm{N} / 10^{\circ} \mathrm{W}-60^{\circ} \mathrm{W}\right)$

[24] The North Atlantic phytoplankton community is dominated all yearlong by nanoeucaryotes, as shown in Figure $8 \mathrm{a}$. The diatom dominant contribution however increases significantly during the spring bloom, between May and August. Figure 8b shows that the North Atlantic Chl-a starts to increase in February, following the stratification of waters and the increase of sea surface temperature as shown in Figure 8c. Note that the temperature start to increase in March-April, as diatoms, after the beginning of the Chl-a increase. This observed shift is also certainly due to the specificity of PHYSAT, which allows to detect a group only when it become dominant, i.e., accounts for more than $60 \%$ of the whole phytoplankton [Alvain et al., 2005]. The onset of the North Atlantic spring bloom is thus 

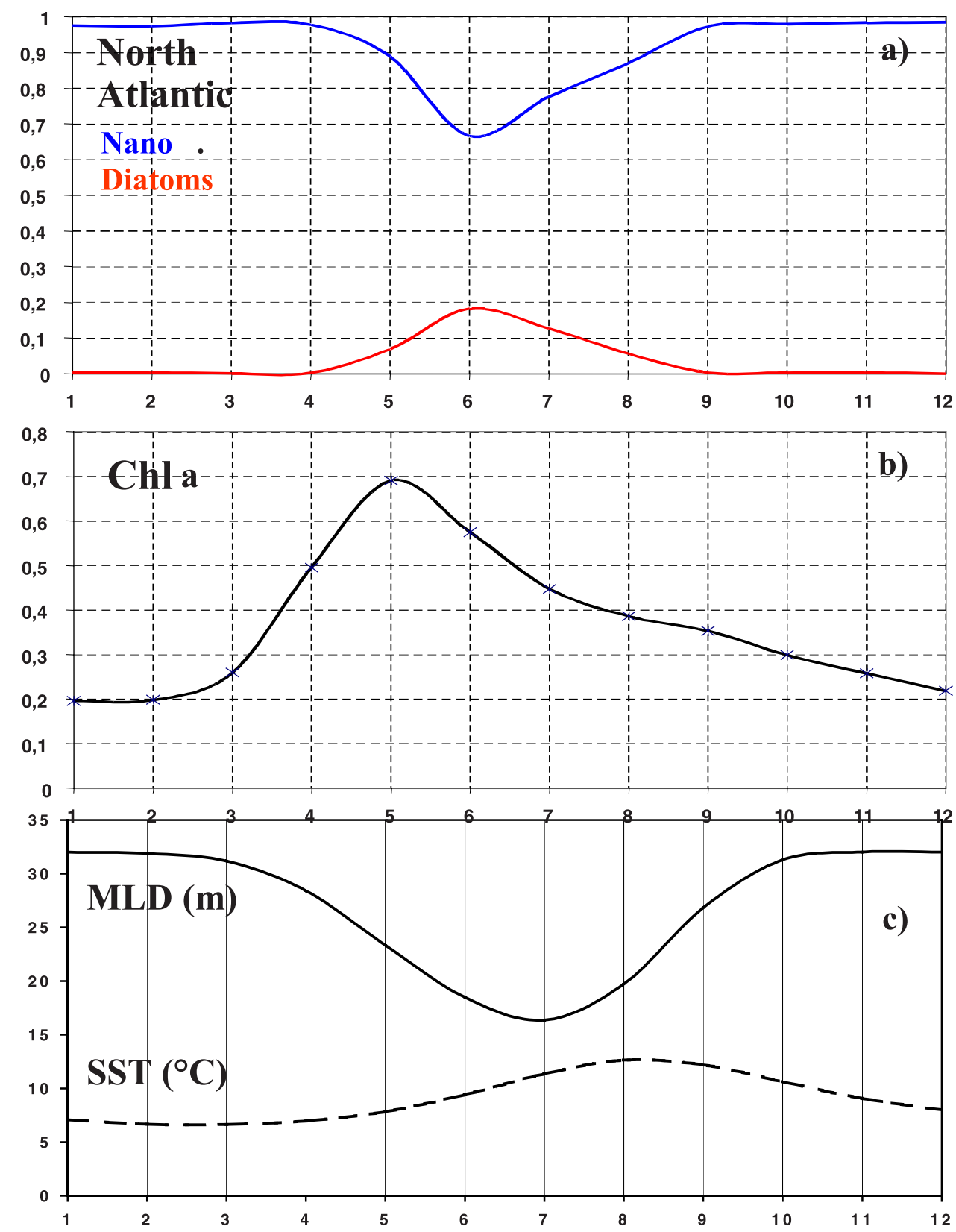

Months

Figure 8. Mean seasonal evolution over the 1998-2006 period of: (a) the relative contribution of each phytoplankton group to the mean chlorophyll-a concentration for the North Atlantic Ocean $\left(40^{\circ} \mathrm{N}-70^{\circ} \mathrm{N} /\right.$ $\left.60^{\circ} \mathrm{W}-20^{\circ} \mathrm{W}\right),(\mathrm{b})$ the mean global chlorophyll-a concentration, and (c) the mean mixed layer depth [Le Quéré et al., 2006] and the mean sea surface temperature (from ICDOADS -http://www.cdc.noaa.gov). Only groups that contribute for more than $5 \%$ for at least 1 month in the year are shown in this figure.

likely in March, certainly in waters with diatoms but not dominant in terms of PHYSAT criteria until April.

[25] Figure 9 shows that behind the general patterns evidenced by the climatology (see Figure 4), there is an important interannual variability in the amplitude and evolution of this diatom spring bloom. In addition to start and end latter in 2001 than in 2005, the spring bloom has also very different patterns with more diatoms detected between $40^{\circ} \mathrm{N}$ and $50^{\circ} \mathrm{N}$ in 2001 and between $50^{\circ} \mathrm{N}$ and $60^{\circ} \mathrm{N}$ in 2005 . This variability is likely controlled by differences in water stratification and nutrient availability, as well as in light and temperature conditions from one year to another [Leblanc et al., 2005]. Another implication of this strong geographical variability of the bloom is that the diatoms contribution 


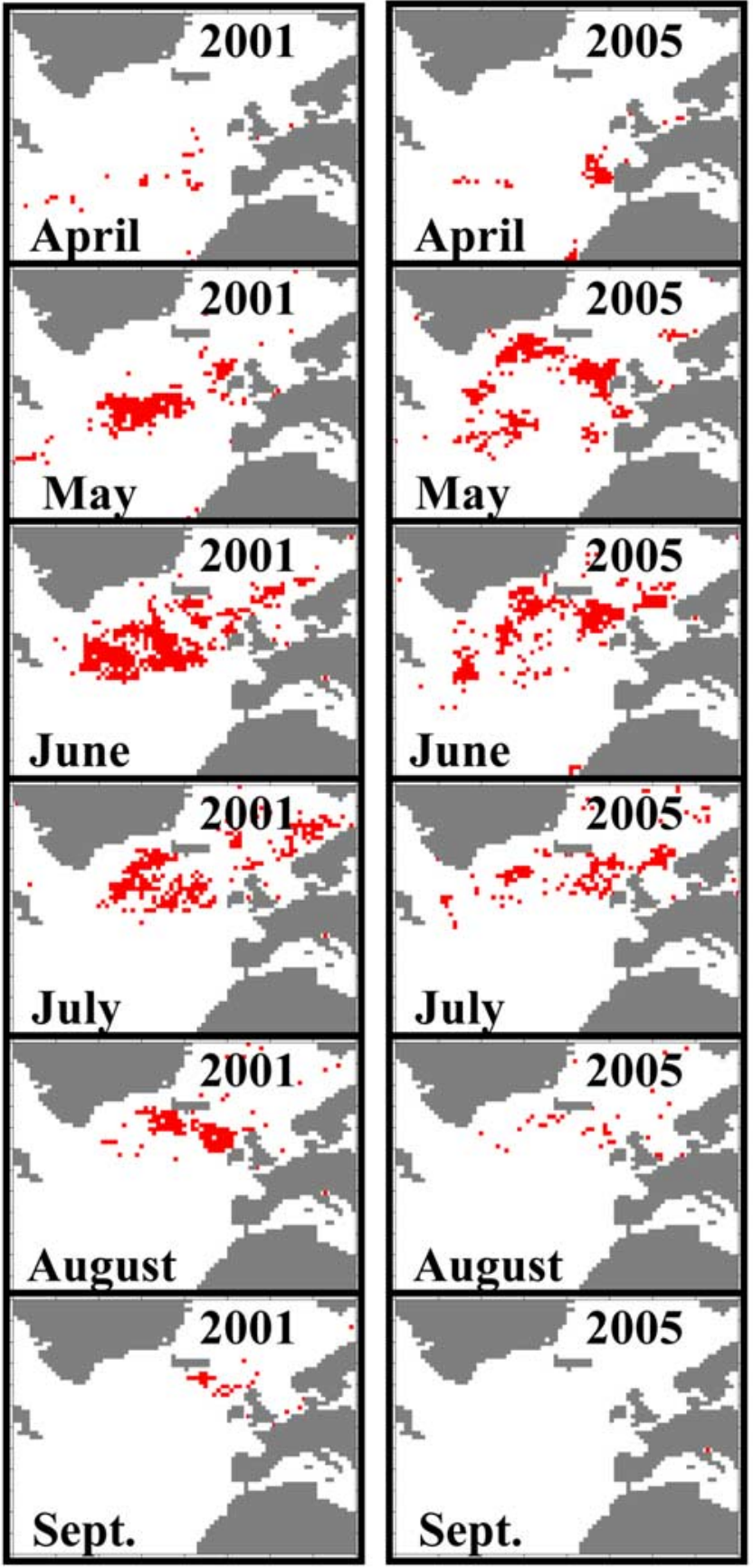

Figure 9. Comparison of evolution of the North Atlantic diatoms spring bloom (in red) for years 2001 and 2005.

deduced from the climatology in Figure 4 is probably underestimated.

\subsection{Southern Ocean $\left(40^{\circ} \mathrm{S}-70^{\circ} \mathrm{S} / 180^{\circ} \mathrm{W}-180^{\circ} \mathrm{E}\right)$}

[26] The particularities of this region are a seasonal icecover and strong physical forcing. These specificity, associated with the absence of coastline and a specific topography, induce strong currents and nutrient inputs as well as large discontinuity front areas. All these characteristics associ- ated with seasonal light variability allow large phytoplankton blooms in spring and summer. As shown in the climatology of Figure 4, these conditions facilitate the development of large blooms of both diatoms and phaeocystis-like. The diatoms blooms start and finish in the convergence zone around $40^{\circ} \mathrm{S}$, respectively in October and April [Tremblay et al., 2002], while they cover most of the southern Ocean in December and January [Smetacek et al., 1990]. From November to March, diatoms blooms move similarly than in the Northern Hemisphere, i.e., from low to high latitudes, following the apparition of favorable conditions. In December and January, diatoms are detected also near the melting zone and along the stratified marginal ice zone as observed in the Ross Sea [Mangoni et al., 2004; Goffart et al., 2000; Smith et al., 2003]. The widest phaeocystis-like blooms are detected in January and February, after diatoms blooms, mostly in the southern Indian Ocean and South of Patagonia. Large patches of Synechococcus are also detected in association with diatoms in the convergence zone between $40^{\circ}-50^{\circ} \mathrm{S}$, as reported by Zubkov et al. [2000]. They are known to appear when conditions are not or no more favorable to diatoms, for example when the silicate concentration, which is essential to diatoms, is reduced to limiting values [Peeken, 1997; Selph et al., 2001].
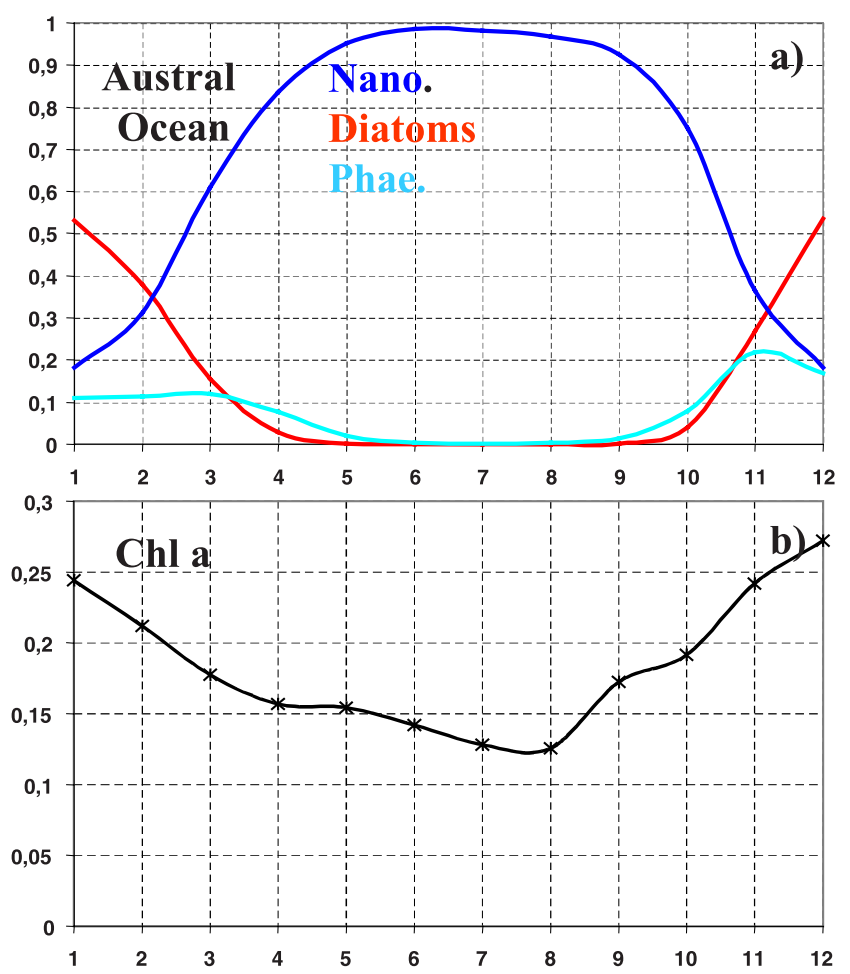

Figure 10. Mean seasonal evolution over the 1998-2006 period of: (a) the relative contribution of each phytoplankton group to the mean chlorophyll-a concentration for the Southern Ocean $\left(40^{\circ} \mathrm{S}-70^{\circ} \mathrm{S} / 180^{\circ} \mathrm{W}-180^{\circ} \mathrm{E}\right)$ and (b) the mean global chlorophyll-a concentration. Only groups that contribute for more than 5\% for at least 1 month in the year are shown in this figure. 


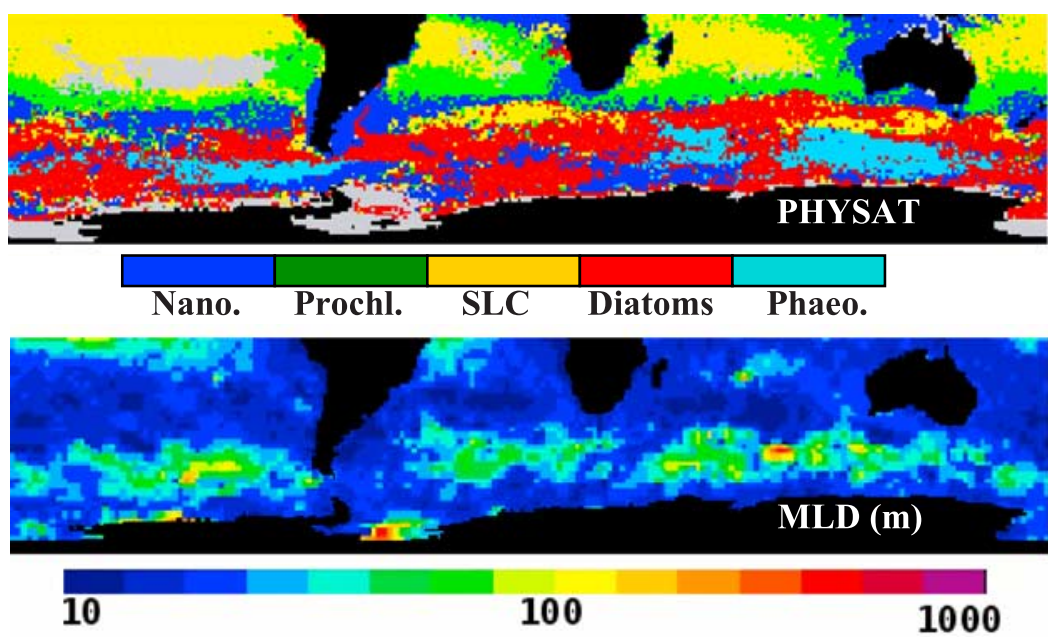

Figure 11. Comparison for the month of January of the climatology of the dominant phytoplankton group with the climatology of the mixed layer depth (in meters) from de Boyer Montégut et al. [2004].

[27] Figure 10 shows the strong seasonal cycle in the group contribution to the chlorophyll-a. Nanoeucaryotes are responsible for most of the chlorophyll-a in the southern Ocean from March to October, but their contribution drops down to less than $50 \%$ from November to January when phaeocystis-like and diatoms are blooming to reach respectively $20 \%$ and $50 \%$ of the chlorophyll-a. According to PHYSAT, diatoms and to a lesser extent phaeocystis-like are thus the two main groups dominant in winter. This is in agreement with our current knowledge about the distributions of diatoms and phaeocystislike, which are known to be major phytoplankton groups in winter in the nutrient-rich southern Ocean [Longhurst, 2007]. As in the North Atlantic, and likely for the same methodological reason, Figure 7 shows that Chl-a starts to increase before PHYSAT detects an increase in the diatoms and phaeocystis-like coverage. It is also known that the geographical distribution of these two groups is strongly controlled by the thickness of the mixed layer. diatoms are found preferentially in stratified waters which allow the bloom development [Weber and El-Sayed, 1987; Jochem et al., 1995], whereas phaeocystis-like usually prevails in regions of deep mixed layer [Arrigo et al., 1999; Goffart et al., 2000; Mangoni et al., 2004]. The comparison of the PHYSAT climatological map with a climatology of the mixed layer depth [de Boyer Montégut et al., 2004] for January shown in Figure 11 confirms this environmental control of the dominance of each group, mainly in the southern Indian and Pacific Oceans.

\subsection{Equatorial Pacific $\left(5^{\circ} \mathrm{S}-5^{\circ} \mathrm{N} / 80^{\circ} \mathrm{W}-170^{\circ} \mathrm{W}\right)$}

[28] The eastern Equatorial Pacific is of special interest for the global carbon cycle because it behaves both as a large natural source of $\mathrm{CO} 2$ for the atmosphere and as a sink through primary production, which induces atmospheric CO2 uptake [Murray et al., 1995]. The equatorial Pacific is characterized by high nutrient concentrations, brought up by the quasi-permanent upwelling. However, Chl-a remains relatively low, so that this region has been described as having High Nutrients-Low Chlorophyll characteristics (HNLC [Thomas, 1979]). This apparent paradox is explained by the steady upwelling conditions, that favor high level of grazer population, and thus limit the growth of the phytoplankton [Walsh, 1976; Cullen, 1991], or by the lack of iron [Coale et al., 1996], or by both factors [Landry et al., 1997].

[29] The PHYSAT climatology in Figure 4 shows a large dominance of Synechococcus and Prochlorococcus in the Equatorial Pacific all yearlong, in agreement with available observations which show that phytoplankton community in this region is dominated by small cells, less than $5 \mu \mathrm{m}$ in diameter [Chavez et al., 1999]. Even with PHYSAT uncertainty explain in section 1.3 about Synechococcus and Prochlorococcus distinction in this region, the Synechococcus contribution to the total Chla seems to higher (be 3 to 8 times) than that of Prochlorococcus, as shown in Figure 12a. Figure 12b shows that there is no clear correlation between the variation of the contribution of these two groups and the variation of the total Chl-a over the area. On the contrary the seasonal evolution of the diatoms contribution in the Equatorial Pacific resembles that of the total Chl-a (Figure 12c). It is generally admitted that diatoms do not contribute to more than $20 \%$ of phytoplankton biomass [Blanchot et al., 2001; Kobayashi and Takahashi, 2002; Dandonneau et al., 2004] in this region, but blooms however have been exceptionally reported in this area [Bender and McPhaden, 1990; Chavez et al., 1990; Archer et al., 1997]. How common are such diatoms blooms in the Equatorial Pacific remains unknown because of the paucity of in situ measurements. They may break out when equatorial upwelling is intense and non limited to the coastal region, as shown in Figure 13, corresponding to "La Niña" event of 1998 bringing large amounts of nutrients into the photic layer [Strutton and Chavez, 2000; Ryan et al., 2002]. Iron limitation is especially important for diatoms, which 

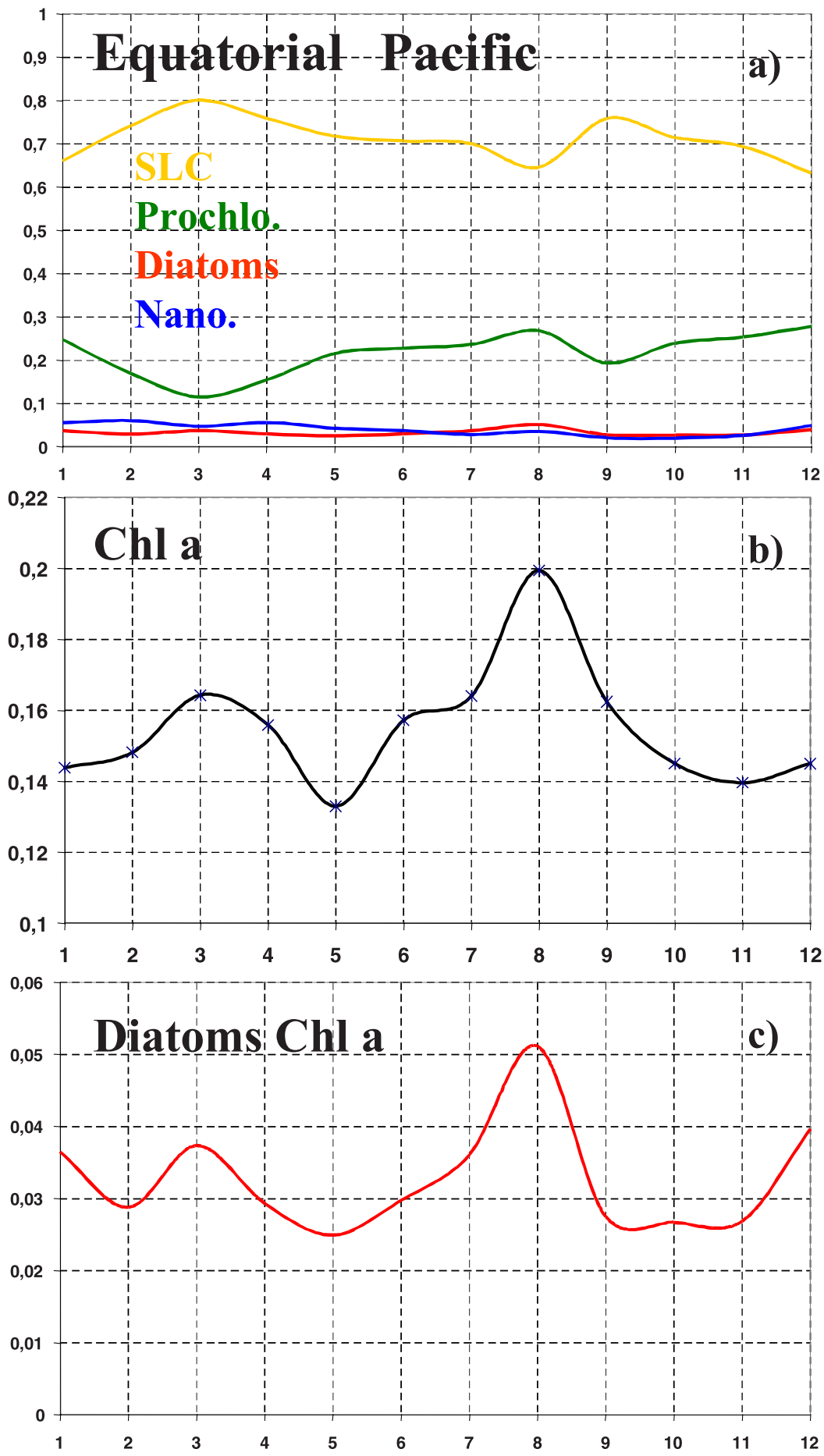

Figure 12. Mean seasonal evolution over the 1998-2006 period of: (a) the relative contribution of each phytoplankton group to the mean chlorophyll-a concentration for the Equatorial Pacific $\left(5^{\circ} \mathrm{S}-5^{\circ} \mathrm{N} /\right.$ $\left.170^{\circ} \mathrm{W}-80^{\circ} \mathrm{W}\right)$, (b) the mean chlorophyll-a concentration, and (c) the mean chlorophyll-a concentration associated with diatoms. Only groups that contribute for more than 5\% for at least 1 month in the year are shown in this figure. 


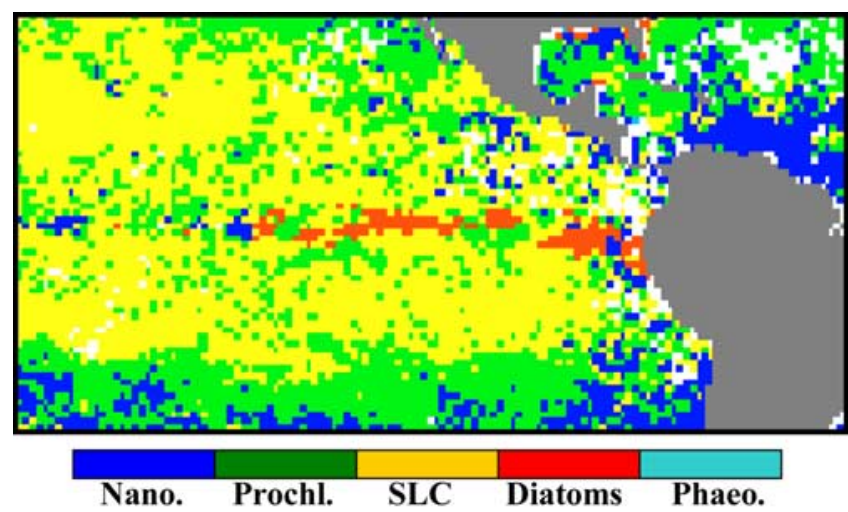

Figure 13. The unusual diatom bloom in the Equatorial Pacific region in August 1998.

need high iron concentration to achieve maximum growth rates. When nutrients and iron are abundant in the photic layer, diatoms grow rapidly, dominate the phytoplankton population, and give rise to massive exports of organic carbon to the sediment as shown by Greene et al. [1991], Cavender-Bares et al. [1999], and Boyd et al. [1998].

\section{Conclusion}

[30] PHYSAT [Alvain et al., 2005] is a classification technique that allows to identify four major phytoplankton groups (diatoms, Prochlorococcus, Synechococcus, nanoeucaryotes) from the spectral shape of the normalized waterleaving radiance $(\mathrm{nLw})$ of the SeaWiFS ocean color sensor. In this paper, we have slightly modified PHYSAT by improving the $\mathrm{nLw}$ normalization technique. The identification of an additional group, phaeocystis-like, is also discussed.

[31] This new version of PHYSAT has been applied to the SeaWiFS archive (1998-2006) of daily global level-3 products. A validation of PHYSAT monthly maps are presented using GeP\&CO and NOMAD pigments data set. Percentage of valid and wrong diagnostics are detailed according to each group. PHYSAT monthly maps were next used to derive a monthly climatology of the distribution of dominant phytoplankton groups in the world ocean. The climatology shows that nanoeucaryote is the dominant species at the global scale. Its contribution to the global biomass varies between $45 \%$ in winter and $75 \%$ in summer. This group is mostly observed at mid and high latitudes, whereas Prochloroccocus and Synechococcus prevail in tropical waters. Synechococcus contribute to about $15 \%$ of the global biomass and is mostly observed in highly oligotrophic waters, whereas Prochloroccocus are found in more productive regions, even if they contribute only to about $10 \%$. In summertime, diatoms invade almost entirely the Southern Ocean, as phaeocystis-like to a lesser extent.

[32] A regional analysis of the climatology highlights the major role of diatoms on the seasonal cycle of the primary production at high latitudes. Their contribution accounts for up to $20 \%$ (respectively $50 \%$ ) of the total Chl-a in the North Atlantic (respectively Southern Ocean) in June (respectively in January and December). The North Atlantic diatoms bloom shows a very large interannual variability, in terms of both timing and geographical location. Large phaeocystis-like blooms are also detected in the Southern Ocean, with a maximum contribution of $20 \%$ of the total Chl-a in November and December, i.e., one month before the period of maximum diatoms contribution. A comparison with a climatology of the mixed-layer depth [de Boyer Montégut et al., 2004] reveals that phaeocystis-like have affinities with deep mixed-layers and diatoms prevailing in the more stratified waters.

[33] The last region that has been studied in details in this paper is the Equatorial Pacific. Synechococcus and Prochloroccocus, prevail in this region, but our archive shows that the ecosystem structure is sensitive to climate variability. Thus when nutrients and iron are abundant in the photic layer, diatoms can also grow rapidly and dominate the phytoplankton population.

[34] These regional analyses demonstrate the importance of the PHYSAT archive presented in this paper to improve our knowledge on the temporal and geographical distribution of the major phytoplankton groups at the global scale, but also to study the impact of climate variability on ecosystems. More detailed analyses of the mechanisms responsible for these controls should allow to a better prediction of the impact of ongoing climate change on the composition of marine ecosystems.

[35] Acknowledgments. The authors thank NASA/GSFC/DAAC for providing access to daily L3 SeaWiFS binned products and the European Network of excellence for ocean ecosystems analysis for funding. They also thank L. Bopp and C. Lequere for their pertinent comments and R. Sion for his technical help.

\section{References}

Alvain, S., C. Moulin, Y. Dandonneau, and F. M. Bréon (2005), Remote sensing of phytoplankton groups in case 1 waters from global SeaWiFS imagery, Deep Sea Res., Part I, 52.

Alvain, S., C. Moulin, Y. Dandonneau, H. Loisel, and F. M. Bréon (2006), A species-dependent bio-optical model of case 1 waters for global ocean color processing, Deep Sea Res., Part I, 53.

Archer, D., et al. (1997), A meeting place of great ocean currents: Shipboard observations of a convergent front at $2^{\circ} \mathrm{N}$ in the Pacific, Deep Sea Res., Part II, 44.

Arrigo, K. R., D. H. Robinson, D. L. Worthen, R. B. Dunbar, G. R. DiTullio, M. VanWoert, and M. L. Lizotte (1999), Phytoplankton community structure and the drawdown of nutrients and $\mathrm{CO} 2$ in the Southern Ocean, Science, 283.

Aumont, O., E. Maier-Reimer, S. Blain, and P. Monfray (2003), An ecosystem model of the global ocean including $\mathrm{Fe}, \mathrm{Si}, \mathrm{P}$ colimitations, Global Biogeochem. Cycles, 17(2), 1060, doi:10.1029/2001GB001745.

Belviso, S., C. Moulin, L. Bopp, and J. Stefels (2004), Assessment of a global climatology of oceanic dimethylsulfide (DMS) concentrations based on SeaWiFS imagery (1998-2001), Canadian, J. Fish. Aquat. Sci., 61(5).

Bender, M. L., and M. J. McPhaden (1990), Anomalous nutrient distribution in the equatorial Pacific in April 1988: Evidence for rapid biological uptake, Deep Sea Res., Part I, 37.

Blanchot, J., J.-M. André, C. Navarette, J. Neveux, and M.-H. Radenac (2001), Picophytoplankton in the equatorial Pacific: Vertical distributions in the warm pool and in the high nutrient low chlorophyll conditions, Deep Sea Res., Part I, 48.

Bopp, L., P. Monfray, O. Aumont, J. L. Dufresne, H. L. Treut, G. Madec, L. Terray, and J. C. Orr (2001), Potential impact of climate change on marine export production, Global Biogeochem. Cycles, 15(1).

Bopp, L., O. Aumont, P. Cadule, S. Alvain, and M. Gehlen (2005), Response of diatoms distribution to global warming and potential implications: A global model study, Geophys. Res. Lett., 32(19), L19606, doi:10.1029/2005GL023653. 
Boyd, P. W., C. S. Wong, J. Merrill, F. Whitney, J. Snow, P. J. Harrison, and J. Gower (1998), Atmospheric iron supply and enhanced vertical carbon flux in the NE subarctic Pacific: Is there a connection?, Global Biogeochem. Cycles, 12, 429-441.

Brown, C. W., and J. A. Yoder (1994), Coccolithophorid blooms in the global ocean, J. Geophys. Res., 99, 7467-7482.

Cavender-Bares, K. K., E. L. Mann, S. W. Chisolm, M. E. Ondrusek, and R. L. Bidigare (1999), Differential response of equatorial Pacific phytoplankton to iron fertilization, Limnol. Oceanogr., 44.

Chavez, F. P., K. R. Buck, and R. T. Barber (1990), Phytoplankton taxa in relation to primary production in the equatorial Pacific, Deep Sea Res. 37.

Chavez, F. P., P. G. Strutton, G. E. Friedrich, R. A. Feely, G. C. Feldman, D. G. Foley, and M. J. McPhaden (1999), Biological and chemical response of the equatorial Pacific ocean to the 1997-98 EL Niño, Science, 286.

Coale, K. H., S. E. Fitzwater, R. M. Gordon, K. S. Johnson, and R. T. Barber (1996), Control of community growth and export production by upwelled iron in the equatorial Pacific Ocean, Nature, 379, 621-624.

Cox, P. M., R. A. Betts, C. D. Jones, S. A. Spall, and I. J. Totterdell (2000), Acceleration of global warming due to carbon-cycle feedbacks in a coupled climate model, Nature, 408.

Croot, P. L., K. Andersson, M. Ozturk, and D. R. Turner (2004), The distribution and speciation of iron along $6^{\circ} \mathrm{E}$ in the Southern Ocean, Deep Sea Res., Part II, 51.

Cullen, J. J. (1991), Hypotheses to explain high-nutrient conditions in the open sea, Limnol. Oceanogr., 36.

Dandonneau, Y., and A. Niang (2007), Assemblages of phytoplankton pigments along a shipping line through the North Atlantic and Tropical Pacific, Prog. Oceanogr., 73.

Dandonneau, Y., P.-Y. Deschamps, J.-M. Nicolas, H. Loisel, J. Blanchot, Y. Montel, F. Thieuleux, and G. Bécu (2004), Seasonal and interannual variability of ocean color and composition of phytoplankton communities in the North Atlantic, Equatorial Pacific and South Pacific, Deep Sea Res., Part II, 51.

Dandonneau, Y., Y. Montel, J. Blanchot, J. Giraudeau, and J. Neveux (2006), Temporal variability in phytoplankton pigments, picoplankton and coccolithophores along a transect through the North Atlantic Ocean and tropical southwestern pacific, Deep Sea Res., Part I, 53.

de Boyer Montégut, C., G. Madec, A. S. Fischer, A. Lazar, and D. Iudicone (2004), Mixed layer depth over the global ocean: An examination of profile data and a profile-based climatology, J. Geophys. Res., 109, C12003, doi:10.1029/2004JC002378.

DiTullio, G. R., J. M. Grebmeier, K. R. Arrigo, M. P. Lizotte, D. H. Robinson, A. Leventer, J. P. Barry, M. L. VanWoert, and R. B. Dunbar (2000), Rapid and early export of phaeocystis Antarctica blooms in the Ross Sea, Antarct. Nature, 404

Dufresnes, J. L., P. Friedlingstein, M. Berthelot, L. Bopp, P. Ciais, L. Fairhead, H. Le Treut, and P. Monfray (2002), On the magnitude of positive feedback between future climate change and the carbon cycle, Geophys. Res. Lett., 29(10), 1405, doi:10.1029/2001GL013777.

DuRand, M. D., R. J. Olson, and S. W. Chisholm (2001), Phytoplankton population dynamics at the Bermuda Atlantic time-series station in the Sargasso Sea, Deep Sea Res., Part II, (48).

Goffart, A., G. Catalano, and J. H. Hecq (2000), Factors controlling the distribution of diatoms and phaeocystis in the Ross Sea, J. Mar. Syst., 27, $161-175$.

Greene, R. M., R. J. Geider, and P. G. Falkowski (1991), Effect of iron on photosynthesis in a marine Diatom, Limnol. Oceanogr., 36.

Gregg, W. W., P. Ginoux, P. S. Schopf, and N. W. Casey (2003), Phytoplankton and iron: validation of a global three-dimensional ocean biogeochemical model, Deep Sea Res., 50.

Iglesias-Rodríguez, D., C. W. Brown, S. C. Doney, J. Kleypas, D. Kolber, Z. Kolber, P. K. Hayes, and P. G. Falkowski (2002), Representing key phytoplankton functional groups in ocean carbon cycle models: Coccolithophorids, Global Biogeochem. Cycles, 16(4), 1100, doi:10.1029 $2001 \mathrm{~GB} 001454$.

Jeffrey, S. W., and M. Vesk (1997), Introduction to marine phytoplankton and their pigment signatures, in Phytoplankton Pigments in Oceanography: Guidelines to Modern Methods, edited by S. W. Jeffrey, R. F. C. Mantoura, and S. W. Wright, pp. 37-84, Monogr. on Oceanogr. Methodol., SCOR-UNESCO, Paris.

Jochem, F. J., et al. (1995), Size fractionated primary production in the open Southern Ocean in austral spring, Polar, 15.

Kamykowski, D., and G. S. Janowitz (1999), An expanded Eulerian model of phytoplankton environmental response, Ecol. Modell., 118, 2-3.

Knox, G. A. (1994), The Biology of the Southern Ocean, 444 pp., Cambridge Univ. Press, New York.
Kobayashi, F., and K. Takahashi (2002), Distribution along the equatorial transect in the western and central Pacific during the 1999 La Niña conditions, Deep Sea Res., Part II, 49.

Lampitt, R. S. (1985), Evidence for the seasonal deposition of detritus to deep-sea floor and it subsequent resuspension, Deep Sea Res., Part I, 32. Lancelot, C., P. Wassmann, and H. Barth (1994), Ecology of phaeocystisdominated ecosystems, J. Mar, 5.

Landry, M. R., et al. (1997), Iron and grazing constraints on primary production in the central equatorial Pacific: An EqPac synthesis, Limnol. Oceanogr., (42).

Leblanc, K., A. Leynart, C. Fernandez, P. Rimmelin, T. Moutin, P. Raimbault, J. Ras, and B. Quéguiner (2005), A seasonal study of diatoms dynamics in the North Atlantic during the POMME experiment (2001): Evidence for $\mathrm{Si}$ limitation of the spring bloom, J. Geophys. Res., 110, C07S14, doi:10.1029/2004JC002621.

Le Quéré, C., and N. Metzl (2004), Natural processes regulating the oceanic uptake of $\mathrm{CO} 2$, in Towards CO2 Stabilization: Issues, Strategies, and Consequences, edited by C. B. Field and M. R. Raupach, Island Press, Washington, D. C.

Le Quéré, C., et al. (2005), Ecosystem dynamics based on plankton functional types for global ocean biogeochemistry models, Global Change Biol., 11 .

Le Quéré, C., I. C. Prentice, and R. B. Rivkin (2006), Modeling interactions between marine ecosystems and climate, Eos Trans. AGU, 87(42), 452, doi:10.1029/2006EO420005.

Lochte, K., H. Ducklow, M. Fasham, and C. Stienens (1993), Plankton succession and carbon cycling at $47^{\circ} \mathrm{N} 20^{\circ} \mathrm{W}$ during the JGOFS North Atlantic bloom experiment, Deep Sea Res., 40.

Longhurst, A. (2007), Ecological Geography of the Sea, 2nd ed., Academic Press, San Diego, Calif..

Mangoni, O., M. Modigh, F. Conversano, G. C. Carrada, and V. Saggiomo (2004), Effects of summer ice coverage on phytoplankton assemblages in the Ross Sea, Antarctica, Deep Sea Res., Part I, (51).

Marty, J. C., and J. Chiavérini (2002), Seasonal and interannual variations in phytoplankton production at DYFAMED time-series station, northwestern Mediterranean Sea, Deep Sea Res., Part II, 49.

Moore, J. K., S. C. Doney, and K. Lindsay (2004), Upper ocean ecosystem dynamics and iron cycling in a global three-dimensional model, Global Biogeochem. Cycles, 18, GB4028, doi:10.1029/2004GB002220.

Murray, J. W., et al. (1995), A US JGOFS process study in the Equatorial Pacific (EqPac), Deep Sea Res., Part II, 42.

O'Reilly, J., S. Maritonera, B. G. Siegel, D. A. Mitchell, K. L. Carder, S. A. Garver, M. Kahru, and C. McClain (1998), Ocean color chlorophyll algorithms for SeaWiFS, J. Geophys. Res., 103(C11), 24,937-24,953.

Patt, F. S., et al. (2003), Algorithm updates for the fourth SEAWIFS data reprocessing, SeaWiFS Postlaunch Technical Report, vol. 22, 206892 NASA Tech. Memo.

Peeken, I. (1997), Photosynthetic pigment fingerprints as indicators of phytoplankton biomass and development in different water masses of the Southern Ocean during austral spring, Deep Sea Res., 44.

Ryan, J. P., P. S. Polito, P. G. Strutton, and F. P. Chavez (2002), Unusual large-scale phytoplankton blooms in the equatorial Pacific, Prog. Int., 55. Sarmiento, J. L., R. Slater, R. Barber, L. Bopp, S. C. Doney, A. C. Hirts, J. Kleypas, and R. Stouffer (2004), Response of ocean ecosystems to climate warming, Global Biogeochem. Cycles, 18, GB3003, doi:10.1029/2003GB002134

Schoemann, V., S. Becquevort, J. Stefels, V. Rousseau, and C. Lancelot (2005), Phaeocystis-like blooms in the global ocean and their controlling mechanisms: A review, J. Sea Res., 53.

Selph, K. E., et al. (2001), Microbial community composition and growth dynamics in the Antarctic Polar Front and seasonal ice zone during late spring 1997, Deep Sea Res., Part II, 48.

Smetacek, V. H., R. Scharek, and E.-M. Nöthig (1990), Seasonal and regional variation in the pelagial and its relationships to the life cycle of Krill, in Antarctic Ecosystems. Ecological Change and Conservation, edited by K. R. Kerry and G. Hempel, pp. 103-114, Springer, New York.

Smith, W. O., Jr, M. R. Dennett, S. Mathot, and D. A. Caron (2003), The temporal dynamics of the flagellated and colomial stages of phaeocystis antarctica in the Ross Sea, Deep Sea Res., Part II, (50).

Steinberg, D. K., et al. (2001), Overvew of the US JGOFS Bermuda Atlantic Time-series Study (BATS): A decade-scale look at ocean biology and biogeochemistry, Deep Sea Res., Part II, 48.

Strutton, P. G., and F. P. Chavez (2000), Primary productivity in the equatorial Pacific during the 1997-1998 El Niño, J. Geophys. Res., 105(C11), $26,089-26,101$

Thomas, W. H. (1979), Anomalous nutrient-chlorophyll interrelationships in the offshore eastern tropical Pacific Ocean, J. Mar. Res., 37. 
Tremblay, J. E., M. I. Lucas, G. Kattner, R. Pollard, V. H. Strass, U. Bathmann, and A. Bracher (2002), Significance of the Polar Front zone for large-sized diatoms and new production during summer in the Atlantic sector of the Southern Ocean, Deep Sea Res., Part II, 49.

Walsh, J. J. (1976), Herbivory as a factor in patterns of nutrient utilization in the sea, Limnol. Oceanogr., 21, 1-13.

Webber, L. H., and S. EL-Sayed (1987), Contribution to the net, nano- and picoplankton flux in the Southern Ocean from sediment trap data, J. Plankton Res., (9).

Werdell, P. J., and S. W. Bailey (2005), AN improved bio-optical data set for ocean color algorithm development and satellite data product validation, Remote Sens. Environ., (98).
Zubkov, M. V., et al. (2000), Picoplankton community structure on the Atlantic Meridional transect: A comparison between seasons, Prog. Oceanogr., 45.

S. Alvain and H. Loisel, LOG, UMR 8187, CNRS-ULCO-USTL, 28 Avenue Foch, BP 80, F-62930, Wimereux, France. (severine.alvain@ univ-littoral.fr)

Y. Dandonneau, IRD, LOCEAN/IPSL, UMR 7159, (UPMC-CNRSIRD), Boîte 100-4, Place Jussieu, F-75252, Paris Cedex 05, France.

C. Moulin, LSCE/IPSL, CNRS-CEA-UVSQ, L'Orme des Merisiers bat 712, pc 132 F-91191 Gif-sur-Yvette, Cedex, France. 